\title{
Professional communities in human resources management
}

\author{
Ruslan Dolzhenko ${ }^{1, *}$, Svetlana Dolzhenko ${ }^{2}$ \\ ${ }^{1}$ Ural Institute of Management - Branch of RANEPA, 8 Marta Str., 70, 620144 Ekaterinburg, Russia \\ ${ }^{2}$ Ural State University of Economics, 8 Marta Str., 66, 620144 Ekaterinburg, Russia
}

\begin{abstract}
The paper discusses the opportunities of professional communities in the sphere of HR management to design and develop the system of professional qualifications. It describes the nature of professional communities and identifies their advantages for public policy. The study provides the results of HR specialists quantity analysis, presents the conclusions of the monitoring of HR professional communities in Russia, determines their readiness to develop the system of professional qualifications in the country. The monitoring included 97 Russian professional communities in HR management. Websites of professional communities have been analysed; the experience of community members has been studied; results of the survey among communities' members held in 2010-2016 are presented. This research helped to identify several new and relevant activities of Russian professional communities in HR management, such as development of an independent qualification assessment and updating of educational programs in higher educational establishments.
\end{abstract}

\section{Introduction}

E. Ostrom, the Nobel Prize winner in economics in 2009, argued that "local, selforganized institutions are a significant asset in the institutional portfolio of humankind, and need to survive into the twenty-first century". One of the forms of such social institutions is professional community that can provide efficient implementation of new mechanisms of interaction between economic agents with the help of communication between the members, exchange of standards, knowledge, and views. Communities may be successful in different spheres, including personnel management.

Professional community is traditionally interpreted as a self-regulating association of people beloning to one profession who carry on its values and standards. The notion itself has been used for quite a long time, professional communities exist since early ages in different forms, for instance, workshop associations, guilds, unions, associations and others. Due to the transition to post-industrial stage in the society development and continuous transformations of organizations the meaning of this concept has been gradually

\footnotetext{
* Corresponding author: snurk17@gmail.com
} 
changing. Belonging to a certain profession is not of primary importance anymore, it is necessary to be an expert in some field. [Martyanova N.A., 2013].

Several years ago protective function was the main function in the work of professional communities; today, however, it has been replaced by the developmental function that aimes at community members progress.

We believe that professional community may be defined as a unity of specialists from different organizations in one professional sphere that communicate on a regular basis to exchange knowledge, experience, practical skills and to search for new ideas and more efficient ways to fulfill various tasks [Dolzhenko R.A., 2015].

The main reasons for specialists to unite in public organizations are the opportunity to exchange unique information, to share experience of problem solving, to promote professional skills and to get access to the necessary information and databases.

So, the purpose of professional community establishment is to improve communication and speed of solving difficult problems urgent for the companies with the help of experts associations and creation of a network of free knowledge and practical experience exchange. Besides, a professional community helps to establich regular intareaction between experts from different organizations and thus provide their effective communication with each other to fulfill professional tasks as quick as possible [Sergeeva A.V., Andreeva T.E., 2014].

The main goals that can be reached by a professional community include the following: preservation of crucially important knowledge and its formalization; exchange of expert knowledge and experience; fast distribution of the best activities; increase of speed of development and integration of innovations; participation in new producs or services design or improvement of quality of the existing product or service; contribution to organizational processes efficiency promotion; reduction of transaction costs (both financial and time expenditures on business operations).

The capabilities, knowledge and experience of company executives, HR specialists, trade union leaders, government and scientific bodies can be united and applied in urgent problems solving. Nowadays many regions have set up different associations to discuss and address the issues of human resources management in various cases related to business, personal and governmental needs. The European Association for People Management is an example of such community of international scale. It was set up in 1962 on the basis of national associations and professional organizations in the field of human resourses managemen in France, Germany, Sweden, Switzerland and the UK. Another example of a similar organization is The World Federation of People Management Associations established in 1976.

The problem of professional communities has become especially urgent in the Russian Federation with the introduction of the system of professional qualifications. We have carried out this research to analyze the possibility to use experience and knowledge of professional HR communities members in development of the necessary sub-system of professional qualifications in HR.

The research was divided into three stages. At the first stage we studied the context of the current situation that determined the necessity of HR communities establishment and discussed various aspects connected with community members. During this stage we identified several problems that communities face while promoting their ideas and fulfilling the tasks. At the second stage we analyzed a number of important questions in the field of HR management that are relevant for HR communities. At the final stage we found the communities" readiness to fulfillment of the nationwide tasks aimed at development of the system of professional qualifications in personnel management.

The time framework of this research is from establishment and beginning of work of the majority of HR communities in Russia in 2010, until data acquisition of the survey held 
among professional communities in the first quarter of 2017. More than 100 Russian professional HR communities have been studied on the basis of the information about their activities published in the official websites of the organizations. Personal experience of participation in professional community has also become relevant for this research, as the authors of the paper are members of Sverdlovsk Region public organization Association of Executives and Specialists in HR Management". Moreover, the study takes into account results of the surveys held within monitoring of professional communities in 2010-2016. The last stage of the research, held in February of 2017, was the part of the monitoring done by the working party of the Council for

Professional Qualifications in HR Management which the authors of this paper took part in.

\section{Materials and Methods}

The research embraces 104 Russian professional HR communities. All the data is collected from the open sources, in most cases they are web sites of these communities.

It is worth mentioning that the first HR communities that are still conducting their activities in the Russian Federation were set up in 1999-2000. The trends in HR community's establishment are shown in Fig. 1.

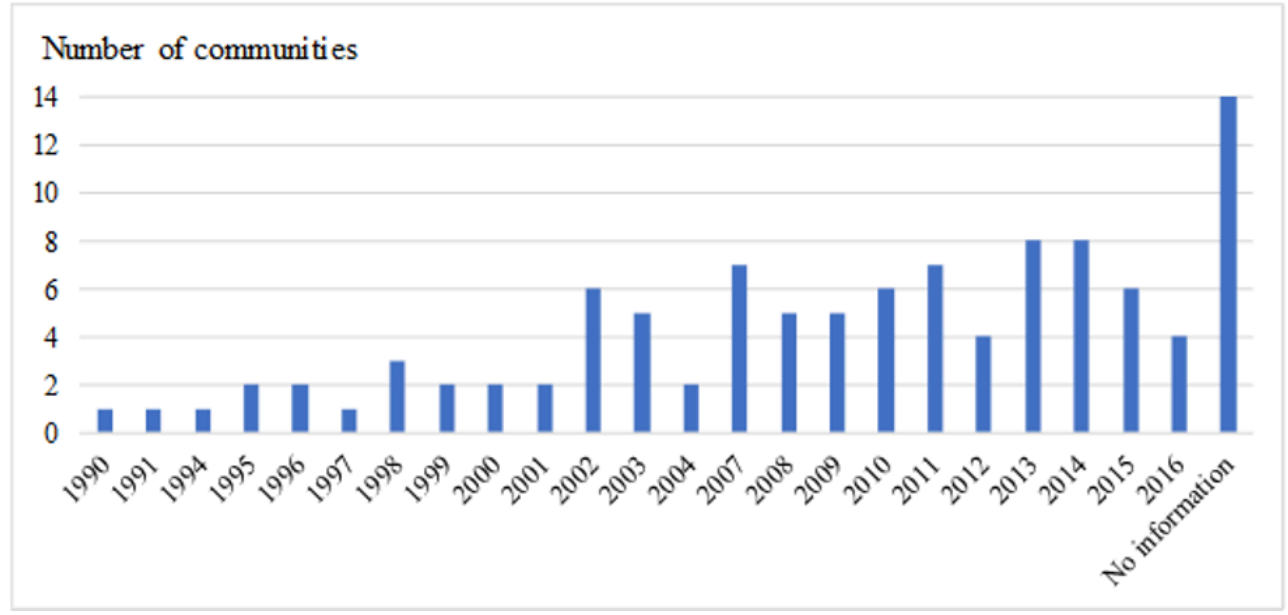

Fig. 1. Dynamics of HR community's establishment in Russia in 1990-2016.

So, we can see that the number of communities started to grow in 2002 with the largest numbers in 2007, 2011, 2013 and 2014. According to community members, the increase of 2010-2011 resulted from the search for the best ways of crisis management and optimization of HR processes during the economic crisis of 2008-2009. That period required exchange of experience and practical skills. In 2015-2016 there was a tendency to lose interest in HR communities, which can be explained by the fact that by that time there was many communities in different regions and all of them were socially active. Besides, there appeared many online communities at that period that replaced classical and formalized communities in some areas. Most of them do not mark the date of their establishment, that is why in Fig. 1. there is a bar showing the number of communities without the exact date of setup (marked as "no information"). Another reason for the drop in the communities' activities is high competition on the part of commercial entities interested in attraction of HR specialists' attention and thus performing many of the classical activities typical of HR communities (for example, master classes and other forms 
of education, including free classes; conferences, forums, etc.). So, almost all large job search websites (HeadHunter, Rabota.ru, SuperJob and others) set up their own HR clubs where they hold different events and exchange information in HR workshops.

The study of communities' activities made it possible to classify these communities based on several parameters:

- form of property:

1. Formalized (with a legal status);

2. Non-formalized (without legal status).

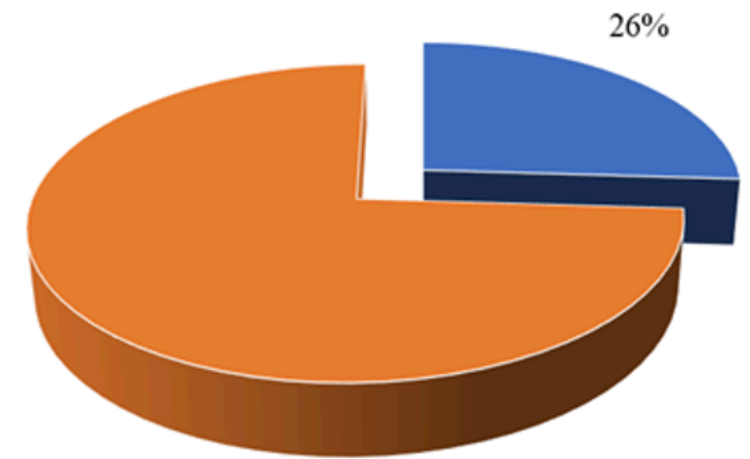

- Formalized community (non-profit partnership, non-profit organization, public interest organization, non-governmental organization)

" Non-formalized community (based on consulting companies, recruitment agencies, educational establishments, Internet-communities, etc.)

Fig. 2. Structure of HR community according to form of property.

Fig. 2. shows that $26 \%$ of communities (or 27 organizations) have a legal status and, as a rule, exist in the form of non-profit organizations controlled by the Federal Law "On Non-profit Organizations". The Law provides the following definition of non-profit organization (article 2) - ,non-profit organization is an entity whose main goal is not related to making profit and it does not distribute profit between the members".

In this research we have found out that the most widespread forms of non-profit organizations are the following: public organizations (associations) that imply voluntary alliance of citizens; non-commercial partnerships and associations (unions) that are set up by citizens and/or juridical persons.

The main reason for a small number of communities with a legal status, according to community members, may be the absence of the necessary time, financial and human resources to register a community and to keep records and make the necessary papers in future.

So, today most HR communities do not have a legal status, they make $74 \%$ of the total number of communities under study. A deeper analysis of the activity of such communities (Fig. 3) revealed that around 50\% of non-formalized communities are established based on organizations whose main aim is to make profit $(29 \%$ of them exist on the basis of consulting companies, $12 \%$ are part of recruitment agencies, $13 \%$ are established on the basis of educational institutions). These communities are headed, as a rule, by the same executive as the founding company. In this case the main goal of establishment of these communities is to make a list of HR specialists who are potential clients to commercial organizations. 


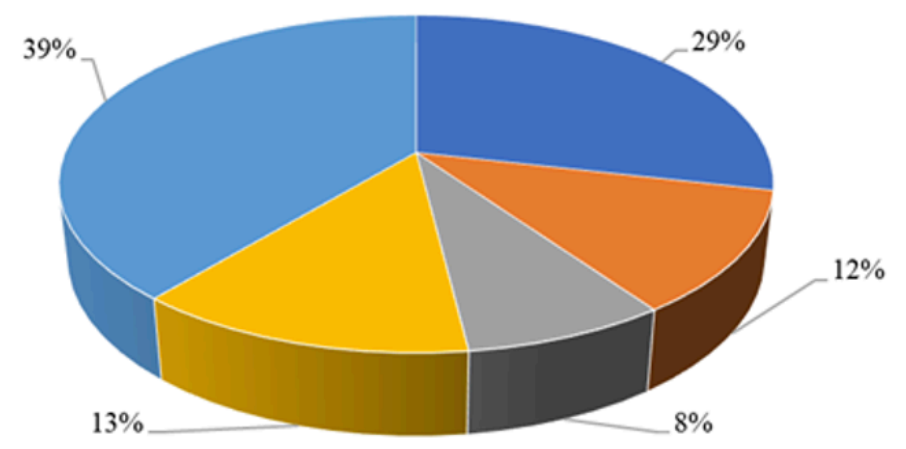

" On the basis of consulting companies

" On the basis of recruitment agencies

- On the basis of large associations (Chamber of Commerce and Industry of the Russian Federation, directors clubs, trainers associations, etc.)

" On the basis of educational institutions

- Other non-formalized communities including those based on the Internet-platforms, Internet mass media, chat rooms. Skvpe. etc.

Fig. 3. Structure of non-formalized HR communities in Russia.

\section{- format of interaction:}

1. Offline (traditional interaction that does not include communication via the Internet);

2. Online (Internet resources; job search websites that unite HR specialists and provide online discussion of the issues related to certain areas of HR).

\section{Results and Discussion}

The research results show that there are very few communities now that work offline only, their proportion is only $4 \%$ of the total number of communities. The number of online communities is growing year by year. Today $17 \%$ of HR communities exist only online and provide interaction on websites, in social networks or chat rooms. This trend is especially popular in HR communities dealing with IT sphere, thus, among the platforms chosen for this research, there are 10 online communities that use Skype for communication between their members. We believe that the rate of online communities will grow in the nearest future, and they will operate on the Internet and in social networks.

- territorial distribution:

Distribution of professional communites in the regions of Russia can be studied with the help of analysis of the number of HR specialists in these regions. We used the information from the statistical report „Number of employed in different territorial subjects of the Russian Federation“" to reveal the number of HR specialists in different regions. 


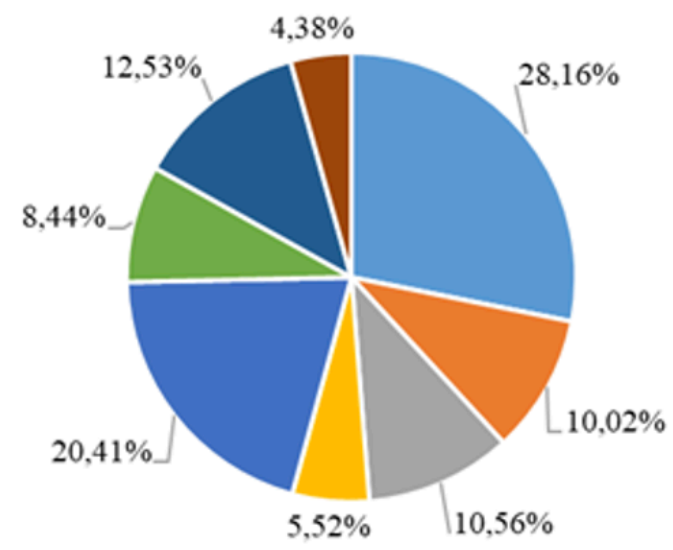

- Central Federal District

" Northwestern Federal District

" Southern Federal District

- North Caucasian Federal District

- Privolzhsky Federal District

- Ural Federal District

- Siberian Federal District

- Far Eastern Federal District

Fig. 4. Structure of professional sphere of „HR management“ in the districts of Russia in 2016.

The largest number of HR specialists work in the following districts:

- Central Federal District (28,16\% of the total quantity of HR specialists in Russia)

- Privolzhsky Federal District $(20,41 \%$ of the total quantity of HR specialists in Russia)

- Siberian Federal District (12,53\% of the total quantity of HR specialists in Russia).

If we compare the results shown in Fig. 4 and 5 we can make a conclusion that there is a direct correlation between the number of HR specialists in the region and amount of professional communities in the same region.

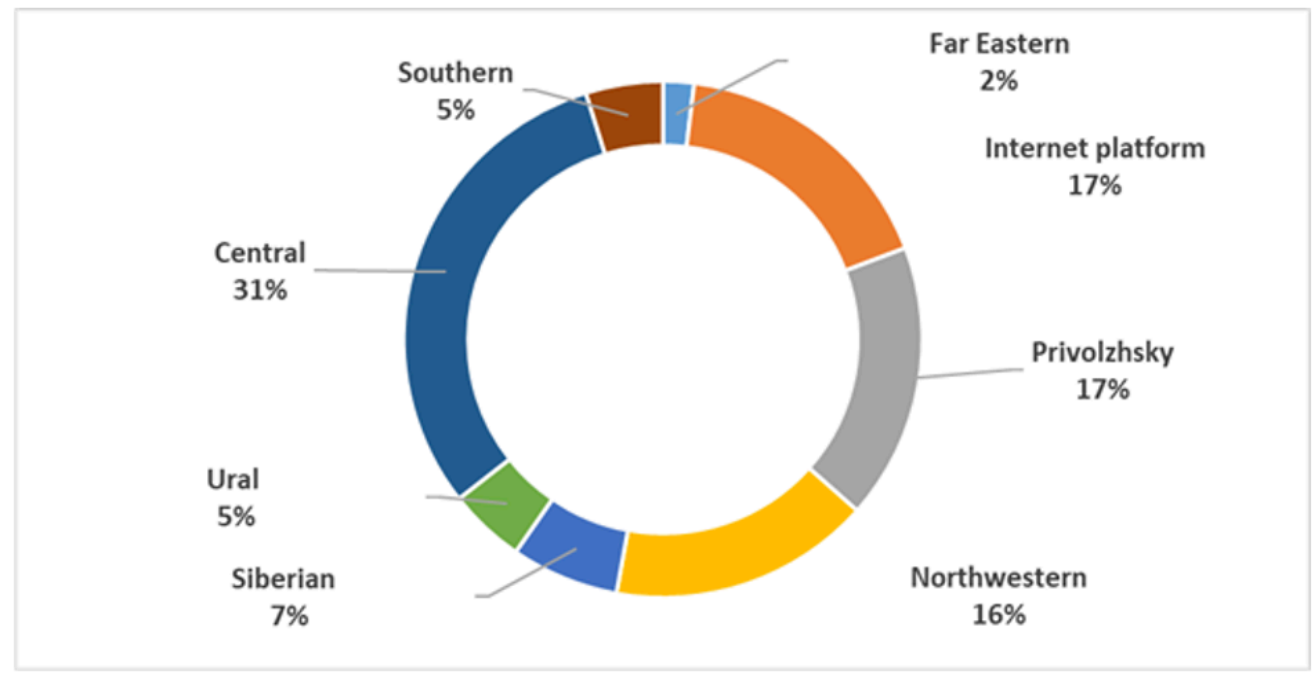

Fig. 5. HR communities in the Districts of the RF, \% of the total number.

Among the regions with the largest number of HR communities (1 and 2 places) are those in which there are more HR specialists:

- Central Federal District (31\% of the total quantity of HR communities)

- Privolzhsky Federal District (17\% of the total quantity of HR communities)

- Internet platforms (17\% of the total quantity of HR communities) 
More details on the distribution of HR communities on the territory of Russia are shown in Table 1.

Table 1. HR communities in Russian Federal Districts.

\begin{tabular}{|c|c|c|}
\hline District & $\begin{array}{l}\text { Number of HR } \\
\text { communities }\end{array}$ & City \\
\hline Central & 32 & $\begin{array}{l}\text { Moscow, Skolkovo, Belgorod, Voronezh, Kaluga, Tver, } \\
\text { Ryazan, Tula, Kursk, Bryansk. }\end{array}$ \\
\hline Privolzhsky & 18 & $\begin{array}{c}\text { Perm, Samara, Saratov, Nizhny Novgorod, Kirov, Ufa, } \\
\text { Kazan, Yelabuga, Saransk. }\end{array}$ \\
\hline Northwestern & 17 & $\begin{array}{l}\text { St. Petersburg, Kaliningrad, Syktyvkar, Vologda, Veliky } \\
\text { Novgorod, Petrozavodsk, Pskov. }\end{array}$ \\
\hline Siberian & 7 & Novosibirsk, Omsk, Irkutsk, Krasnoyarsk. \\
\hline Ural & 5 & Yekaterinburg, Chelyabinsk, Tyumen. \\
\hline Southern & 5 & $\begin{array}{c}\text { Krasnodar, Rostov-On-Don, Sevastopol, Simferopol, } \\
\text { Astrakhan. }\end{array}$ \\
\hline Far Eastern & 2 & Vladivostok, Yuzhno-Sakhalinsk. \\
\hline $\begin{array}{l}\text { Internet } \\
\text { platform }\end{array}$ & 18 & ( \\
\hline Total & 104 & - \\
\hline
\end{tabular}

The first stage of our research made it possible to identify the main members of professional communities; they are: representatives of HR departments of enterprises and organizations; owners and top managers of small and medium-sized enterprises in which there are no HR departments and the managers have to deal with the questions of personnel management themselves; representatives of consulting, recruitment and similar organizations that provide various services in the field of HR management; university lecturers and research officers who have the basic knowledge in the field of personnel management; governmental authorities that deal with the issues of human resources management on the macro-level (for instance, specialists of employment bureaus, employment departments, etc.).

The second stage of research. Topical issues of personnel management for HR communities to deal with

During the study we have summed up the top priorities in professional inetersts of HR specialists and described typical practical tasks of human resources management of economic entities paying special attention to the problematic areas of personnel management: problems and methods used to retain qualified staff; personnel management during business restructuring; optimization of the quantity of staff and expences; technology of corporate culture and HR brand design; developemnt of professional qualifications system (implementation of professional standards in the daily activities of HR management, independent qualification assessment); development of the system of work standardizing and labour organization.

The authors argue that in order to reveal the most important professional topics that are relevant for $\mathrm{HR}$ communities it is necessary to take into account occupational characteristics of specialists. 
According to the labor market monitoring held by the Council for professional qualifications in HR management [Ginieva S.B., Dolzhenko R.A., 2017] we can present the following structure of occupational fields typical of HR management (Fig. 6).

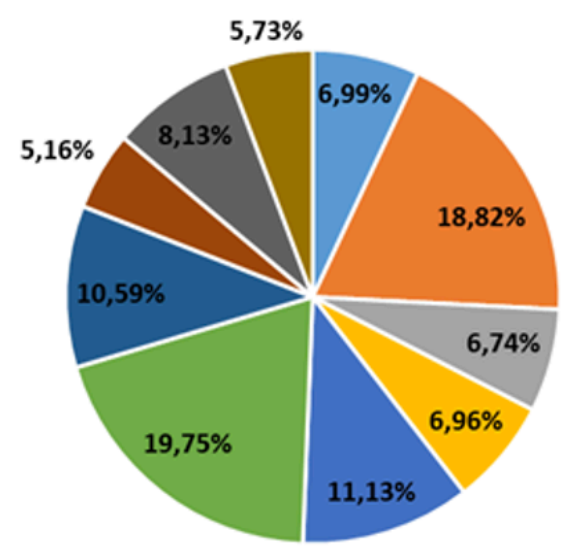

- Overall management of HR system

" HR records keeping

- Labor relations management

= Personnel assessment

- Training and development of staff

- Payroll management

- Motivation of staff

- Recruitment

- Social support of the staff

- Other fields including work

standardizing and labour organization

Fig. 6. Structure of primary fields of activity in HR management.

The proportion of top managers involved in HR sphere is $6.99 \%$ which is 17000 people. Concerning the problem of a pool of experts necessary for professional communities, we believe that this quantity is the potential number of professional community experts in the field of HR capable of presiding over such communities or at least participating in communities of different level.

The structure of HR fields allows for identifying the most popular activites that might be useful for professional communities:

- HR records keeping $(18,82 \%)$;

- Payroll management $(19,75 \%)$;

- Training and development of staff $(11,13 \%)$;

- Motivation of staff (10,59\%).

No doubt, the opportunity to exchange experience of solving applied problems is the most important quality of professional communities, as well as professional competence development and immediate access to the necessary information and databases. However, some public associations that unite specialists in HR management set more ambitious goals, for example:

- support of public discussion and proposals in the area of Russian legislation and regulatory framework in the field of personnel management;

- assistance to establishment of a civilized services market in the field of HR management;

- perfection of the behavior in labor market and employer-employee relationship, human resources management;

- integration of innovations in the sphere of personnel policy within companies.

[Ginieva S.B., Fedorova A.E., 2010].

At the same time, it is necessary to keep in mind the problems that an HR community may face at the initial stage of its establishment. They include:

- conservative attitude of many HR managers who reject new trends and do not seek selfdevelopment; 
- inactivity of HR specialists caused by a growing number of duties as a result of staff quantity optimization;

- cautious attitude to colleagues who are treated as competitors rather than partners, especially if HR specialists work in the rival companies because of the fear that they may be tempted away.

The study made it possible to single out several new and important areas in HR communities' activities that could considerably improve their performance compared to that of the currently existing ones. These communities are focused mainly on events that do not possess a solid structure and do not deal with the socially relevant issues aimed at perfection of the personnel management system in general on the levels of a company and the state.

Among such areas we may find introduction of standards in HR management and design of an independent qualifications assessment. Development of the system of professional qualifications in HR management was initiated by the adoption of the legal and regulatory papers. The relevant documents are the Presidential Decree "On the National Council under the President of the Russian Federation Regarding Professional Qualifications” №249 adopted on April 16, 2014, the Government Decree “On the Plan of Establishment of a Network of Independent Professional Qualifications Accreditation Centers“ №238- $Ф 3$ adopted on July 3, 2016 and others.

A Council for Professional Qualifications in HR management was set up in 2015 to tackle the issues of establishment and development of the system of professional qualifications. Its members are representatives of the interested parties, for example, delegates of the all-Russia associations of employers, professional communities, employers, representatives of professional educational institutions and governmental authorities. [Интернет-сайт Совета по профессиональным квалификациям (СПК) в области управления персоналом// http://sovethr.ru/]. The role of professional communities in the work of the Council is extremely important, that is why one of the stages in this research includes a survey among professional communities leaders to reveal their readiness to develop the system of professional qualifications in their regions.

The survey was held among 55 communities. The communities to be surveyed were picked from the list of 104 professional communities by the research authors together with the experts of the Council for professional qualifications in HR management. According to the survey results, only 17 professional communities $(31 \%$ of the total number of respondent) are ready to cooperate and work on the issues allocated by the government. The main reasons for unpreparedness, according to the communities members are lack of competent experts, lack of financial resources to attract attention to the problem in the regions and to implement independent assessment of qualifications and uncertainty of the economic benefits from the work in this area (this answer is frequent in communities whose main goal is to make profit).

HR communities that are ready to take part in HR professional qualifications system development outlined several areas for cooperation (Fig. 7). 


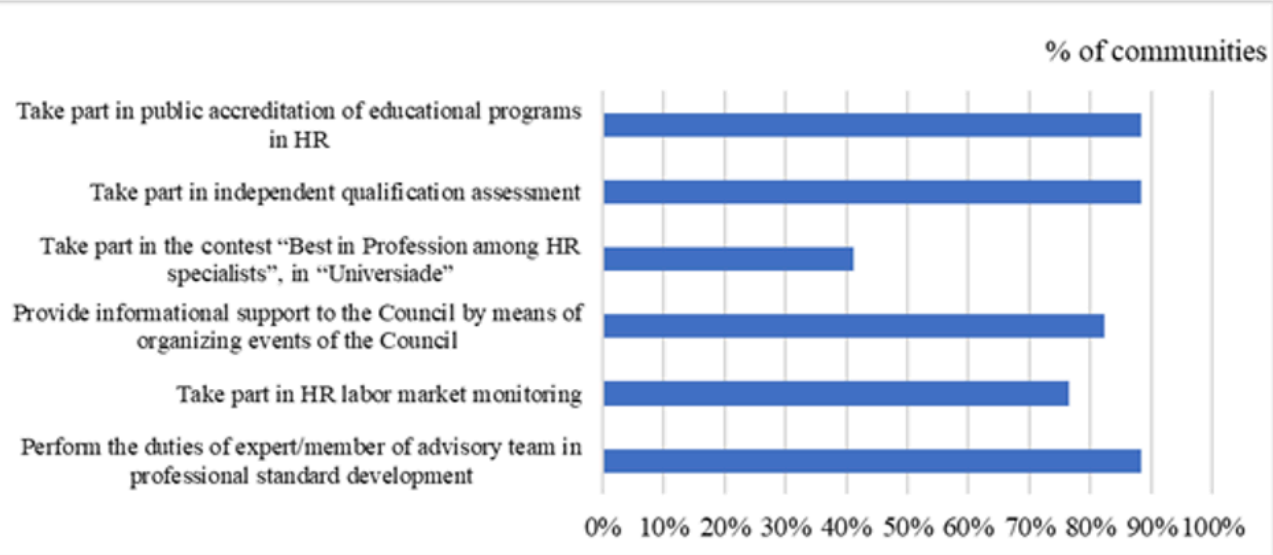

Fig. 7. Areas for cooperation in HR professional qualifications system development.

The most popular areas include:

1. Experts' participation in development and implementation of HR professional standards ( $88 \%$ of all communities in the survey are ready to develop this area)

2. Participation in independent qualification assessment accredited as a Center for Qualifications Assessment (88\% are ready to work in this sphere).

3. Experts' participation in public accreditation of educational programs in HR ( $88 \%$ of communities express their readiness)

Other areas appear to be less attractive, for example, informational support to the Council by means of organizing offline events of the Council is chosen by $82 \%$ of respondents, participation in HR labor market monitoring has $76 \%$ of votes, joint participation in the contest "Best in Profession among HR specialists" and in "Universiade" is mentioned by $41 \%$ of respondents.

We assume that such percentage is determined by the pursuit of commercial activities in most communities. The activities chosen as attractive imply financial benefits, for example independent qualification assessment and accreditation of educational programs.

We believe it is reasonable that the Council for professional qualifications in HR management should consider one more criterion when providing accreditation to professional communities that want to get the rights for independent assessment of qualifications. This criterion should evaluate the community's activity in social spheres and cooperation in all other spheres relevant for the Council, such as development of HR profession, search for the best employees and their support, labor market research, identification of trends in HR sphere, etc.

\section{Conclusions}

Nowadays the role of professional communities in companies, on the labor market, in economics and in society in general has become significant. The nature of relations and their structure are constantly changing. The existing regulations cannot provide the necessary control over companies' activities to ensure safe transactions between the parties. So, organizations set up their own communities to protect themselves and to solve urgent problems. It is especially relevant to HR management due to the state initiative to create an independent system of competences and qualifications. We suppose that it is very important to involve professional community members in fulfillment of this task, otherwise the professional standards and independent qualification assessment will be incomplete. 
This paper provides an overview of the prerequisites of professional communities establishment in today's reality. In our view they help to solve various problems, exchange experience and implement innovations. These activities should be carried out on the basis of institutionalization of professional communities as they are one of the most promising forms of interaction between industrial relations participants, including HR managers. Our study confirmed that there are many employees involved in such activity in Russia. Some of them establish professional communities on their own intiative. We assume that it is of great importance to study professional communities deeper in order to manage this area and use it to the benefit of the whole society.

The results of the analysis presented in the paper are not final. The research will be continued in the field of labor market monitoring within the work of the Council for professional qualifications in HR management.

\section{References}

1. N. A. Martyanova, Construction of Professional Communities: From Professional Groups to Expert Communities, Izvestia: Herzen University Journal of Humanities \& Sciences, 162, 136-140 (2013)

2. R.A. Dolzhenko, Professional communities: opportunities for building and using in the organization, Problems of economics and management of oil and gas organizations, 1, 34-39 (2015)

3. A. V. Sergeeva, T. E. Andreeva, How can management change experience exchange between the employees? Results of the survey in secondary school, Russian journal of management, 12 (2), 67-98 (2014)

4. S. B. Ginieva, R. A. Dolzhenko, HR-community as a tool to fulfill tasks in HR management in Russia and its regions: the problem of qualitative and quantitative assessment, Kadrovik Journal, 1, 52-66 (2017)

5. S. B. Ginieva, A. E. Fedorova, Effective management of human resources: the way to innovative development of the region, Manager, 9-10 (13-14), 44-53 (2010)

6. Z. Ahmed, M. M. Asghar, M. N. Malik, K. Nawaz, Moving towards a sustainable environment: The dynamic linkage between natural resources, human capital, urbanization, economic growth, and ecological footprint in china, Resources Policy, 67 (2020). Access mode: http://doi.org/10.1016/j.resourpol.2020.101677

7. C. Boon, D. N. Den Hartog, D. P. Lepak, A systematic review of human resource management systems and their measurement, Journal of Management, 45 (6), 24982537 (2019). Access mode: http://doi.org/10.1177/0149206318818718

8. J. B. Carnevale, I. Hatak, Employee adjustment and well-being in the era of COVID19: Implications for human resource management, Journal of Business Research, 116, 183-187 (2020). Access mode: http://doi.org/10.1016/j.jbusres.2020.05.037

9. J. Macke, D. Genari, Systematic literature review on sustainable human resource management, Journal of Cleaner Production, 208, 806-815 (2019). Access mode: http://doi.org/10.1016/j.jclepro.2018.10.091

10. S. K. Singh, M. D. Giudice, R. Chierici, D. Graziano, Green innovation and environmental performance: The role of green transformational leadership and green human resource management, Technological Forecasting and Social Change, 150 (2020). Access mode: http://doi.org/10.1016/j.techfore.2019.119762 